\title{
Chemotaxonomic patterns of vegetation and soils along altitudinal transects of the Bale Mountains, Ethiopia, and implications for paleovegetation reconstructions - Part 1: stable isotopes and sugar biomarkers
}

\author{
Betelhem Mekonnen $^{1,2}$, Wolfgang Zech ${ }^{3}$, Bruno Glaser $^{1}$, Bruk Lemma ${ }^{1,4}$, Tobias Bromm ${ }^{1}$, Sileshi Nemomissa ${ }^{5}$, \\ Tamrat Bekele ${ }^{5}$, and Michael Zech ${ }^{1,6}$ \\ ${ }^{1}$ Institute of Agronomy and Natural Sciences, Soil Biogeochemistry, Martin-Luther University, Halle-Wittenberg, \\ Von-Seckendorff-Platz 3, 06120, Halle, Germany \\ ${ }^{2}$ Department of Urban Agriculture, Misrak Polytechnic College, P.O. Box 785, Addis Ababa, Ethiopia \\ ${ }^{3}$ Institute of Soil Science and Soil Geography, University of Bayreuth, 95440 Bayreuth, Universitätsstrasse 30, Germany \\ ${ }^{4}$ Forest and Rangeland Biodiversity Directorate, Ethiopian Biodiversity Institute, P.O. Box 30726, Addis Ababa, Ethiopia \\ ${ }^{5}$ Department of Plant Biology and Biodiversity Management, Addis Ababa University, P.O. Box 3434, Addis Ababa, Ethiopia \\ ${ }^{6}$ Institute of Geography, Technical University of Dresden, Helmholtzstrasse 10, 01062, Dresden, Germany
}

Correspondence: Betelhem Mekonnen (betymekonnen19@gmail.com)

Relevant dates: $\quad$ Received: 9 August 2018 - Revised: 6 March 2019 - Accepted: 25 July 2019 Published: 4 September 2019

How to cite:

Mekonnen, B., Zech, W., Glaser, B., Lemma, B., Bromm, T., Nemomissa, S., Bekele, T., and Zech, M.: Chemotaxonomic patterns of vegetation and soils along altitudinal transects of the Bale Mountains, Ethiopia, and implications for paleovegetation reconstructions - Part 1: stable isotopes and sugar biomarkers, E\&G Quaternary Sci. J., 68, 177-188, https://doi.org/10.5194/egqsj-68-177-2019, 2019.

Abstract:

Today, on the Sanetti Plateau in the Bale Mountains of Ethiopia, only fragmented patches of Erica species can be found at high altitudes (between 3900 and $4200 \mathrm{~m}$ a.s.l.). However, it is hypothesized that during the later part of the last glacial period and the early Holocene the plateau was extensively covered by Erica shrubs. Furthermore, it is assumed that the vegetation was later heavily destroyed by human-induced fire and/or climate change phenomena. The objective of this study is to contribute to paleovegetation reconstructions of the Sanetti Plateau by evaluating the potential of stable isotopes $\left(\delta^{13} \mathrm{C}\right.$ and $\left.\delta^{15} \mathrm{~N}\right)$ and sugar biomarkers for distinguishing the dominant plant species, including Erica, and the soils below the plants. In a companion paper (Lemma et al., 2019a) we address the same issue by evaluating lignin-derived phenols and leaf-wax-derived $n$-alkane biomarkers.

The stable carbon $\left(\delta^{13} \mathrm{C}\right)$ and nitrogen $\left(\delta^{15} \mathrm{~N}\right)$ isotope values of the plant samples range from $-27.5 \%$ to $-23.9 \%$ and $-4.8 \%$ to $5.1 \%$, respectively. We found no significant $\delta^{13} \mathrm{C}$ and $\delta^{15} \mathrm{~N}$ differences between the dominant plant species. Mineral topsoils ( $\mathrm{A}_{\mathrm{h}}$ horizons) yielded more positive values than plant samples and organic layers (O layers), which reflects mineralization processes. Moreover, the $\delta^{15} \mathrm{~N}$ values became generally more negative at higher altitudes. This likely indicates that the $\mathrm{N}$ cycle is more closed compared to lower altitudes. $\delta^{15} \mathrm{~N}$ maxima around $4000 \mathrm{~m}$ a.s.l. point to fire-induced opening of the $\mathrm{N}$ cycle at the chosen study sites. Erica species yielded the lowest overall total sugar concentration (ranging from 58 to $118 \mathrm{mg} \mathrm{g}^{-1}$ ), dominated by galactose $(\mathrm{G})$ and mannose 
(M). By contrast, Festuca species revealed much higher total sugar concentrations ranging from 104 to $253 \mathrm{mg} \mathrm{g}^{-1}$, dominated by the pentose sugars arabinose (A) and xylose (X). Although a differentiation between Erica versus Festuca, Alchemilla and Helichrysum is possible based on $(\mathrm{G}+\mathrm{M}) /(\mathrm{A}+\mathrm{X})$ ratios, Erica cannot be unambiguously distinguished from all other plant species occurring on the Sanetti Plateau. In addition, plant-characteristic $(G+M) /(A+X)$ sugar patterns change during soil organic matter formation in the $A_{h}$ horizons. This can be likely attributed to degradation effects and soil microbial build-up of galactose and mannose. In conclusion, soil degradation processes seem to render sugar biomarker proxies unusable for the reconstruction of the past extent of Erica on the Sanetti Plateau, Bale Mountains, Ethiopia. This finding is of relevance beyond our case study.

Kurzfassung:

Das Sanetti Plateau in den Bale Bergen Äthiopiens ist in seinen höheren Lagen (zwischen 3900 und $4200 \mathrm{~m}$ ü. NN) durch das fragmentarische Vorkommen von Erica geprägt. Möglicherweise kam Erica während des Spätglazials und dem Frühholozän dagegen flächendeckend auf dem Plateau vor und wurde erst im Laufe des Holozäns durch Klimaveränderungen und menschlich verursachte Feuer zurückgedrängt. Das Ziel unserer Studie war es herauszufinden, ob sich die im Untersuchungsgebiet dominant vorkommenden Pflanzenarten einschließlich Erica und die sich unter der jeweiligen Vegetation entwickelten Böden anhand ihrer Stabilkohlenstoff- und Stickstoffisotopien $\left(\delta^{13} \mathrm{C}\right.$ und $\left.\delta^{15} \mathrm{~N}\right)$ sowie ihrer Zucker-Biomarkermuster chemotaxonomisch unterscheiden lassen. In einem Begleitartikel (Lemma et al., 2019a) verfolgen wir dasselbe Ziel anhand von Lignin-bürtigen Phenolen und Blattwachs-bürtigen $n$-Alkan-Biomarkern.

Die $\delta^{13} \mathrm{C}$ und $\delta^{15} \mathrm{~N}$-Werte für die untersuchten Pflanzen reichen von $-27,5 \%$ bis $-23,9 \%$ o bzw. von $-4,8 \%$ o bis $+5,1 \%$ o und weisen keine signifikanten Unterschiede zwischen den dominanten Pflanzenarten auf. Positivere $\delta^{13} \mathrm{C}$ und $\delta^{15} \mathrm{~N}$-Werte in den $\mathrm{A}_{\mathrm{h}}$ Horizonten im Vergleich zu den Pflanzenproben und O-Lagen lassen sich mit der Mineralisations-bedingten Anreicherung von ${ }^{13} \mathrm{C}$ und ${ }^{15} \mathrm{~N}$ in Böden erklären. Tendenziell negativere $\delta^{15} \mathrm{~N}$-Werte mit zunehmender Höhe spiegeln vermutlich wider, dass der N-Kreislauf klimatisch bedingt in größeren Höhen zunehmend geschlossen ist. Lokale $\delta^{15} \mathrm{~N}$ Maxima in etwa $4000 \mathrm{~m}$ Höhe können sehr gut mit der hier feuerbedingten Öffnung des N-Kreislaufs erklärt werden. Erica weist mit 58 bis $118 \mathrm{mg} \mathrm{g}^{-1}$ die niedrigsten ZuckerKonzentrationen auf; es dominieren die Zucker Galactose und Mannose (G und M). Im Gegensatz dazu variieren die Zucker-Konzentrationen im weit verbreitet vorkommenden Gras der Gattung Festuca zwischen 104 und $253 \mathrm{mg} \mathrm{g}^{-1}$; hier dominieren die Zucker Arabinose und Xylose (A und X). Obwohl Erica anhand des $(\mathrm{G}+\mathrm{M}) /(\mathrm{A}+\mathrm{X})$ Verhältnisses von Festuca, Alchemilla und Helichrysum chemotaxonomisch unterschieden werden kann, gilt dies nicht für weitere untersuchte Pflanzenarten wie Kniphofia und Lobelia. Darüber hinaus offenbaren die Datenreihen Pflanze - O-Lage $-\mathrm{A}_{\mathrm{h}^{-}}$ Horizont, dass die zum Teil pflanzencharakteristischen $(G+M) /(A+X)$ Verhältnisse systematischen Veränderungen unterliegen. Dies kann vermutlich auf Degradation und den bodenmikrobiellen Aufbau von Galaktose und Mannose zurückgeführt werden und legt nahe, dass weder anhand von $\delta^{13} \mathrm{C}$ und $\delta^{15} \mathrm{~N}$, noch anhand von Zuckerbiomarkern eine verlässliche Rekonstruktion der Vegetation auf dem Sanetti Plateau möglich ist.

1

The Bale Mountains in the southeast of Ethiopia constitute the largest area with afroalpine and Ericaceous vegetation on the African continent (Hedberg, 1951; Miehe and Miehe, 1994). The area is best known for its large numbers of local endemic flora such as Lobelia rhynchopetalum, Lobelia scebelii and Senecio species (Hillman, 1986). Similar to other tropical high-altitude mountains in East Africa such as Mount Kenya, Mount Kilimanjaro and Mount Meru, the vegetation of the Bale Mountains is characterized by altitu- dinal zones (or belts) with an afromontane forest belt, an Ericaceous belt and an afroalpine belt (Hedberg, 1969; Miehe and Miehe, 1994).

Vegetation reconstructions in the Bale Mountains have been done using mainly pollen records from pit cores (Hamilton, 1982) and sediments (Bonnefille, 1983; Bonnefille and Hamilton, 1986; Umer et al., 2007). Bonnefille (1983) reported, for the Gadeb basin north of the Bale Mountains, on the abundant occurrence of Erica pollen in sediments of a Pliocene lake between 2.5 and 2.4 myr. Pollen records from Mount Badda (north-northwest of the Bale 
Mountains) and the Danka valley (Bale Mountains) suggest that the upper limit of the Ericaceous belt (3830 to $4040 \mathrm{~m}$ a.s.l.) developed between 8000 and 3500 years BP (Bonnefille and Hamilton, 1986; Miehe and Miehe, 1994). A pollen study from Gerba Guracha in the Bale Mountains (Umer et al., 2007) showed that the vegetation after deglaciation at about $16 \mathrm{cal}$ kyr BP mainly consisted of grasses. Only with the beginning of the Holocene at $11 \mathrm{cal} \mathrm{kyr} \mathrm{BP}$ did the Ericaceous belt rise and extend across the Sanetti Plateau, according to Miehe and Miehe, 1994. From about $4.5 \mathrm{cal}$ kyr BP Erica shrubs and forests decreased in area and altitude and the afroalpine ecosystem with Alchemilla and Poaceae species expanded on the Sanetti Plateau. According to Kidane et al. (2012), Miehe and Miehe (1994), Umer et al. (2007), and Wesche et al. (2000), the most likely explanation for the decrease in Erica is fire caused by human invasion. Increasing aridity during the mid to late Holocene (Tiercelin et al., 2008) may have contributed to the destruction of the Erica woodlands on the Sanetti Plateau as well. However, the reason for the contemporary occurrence of only fragmented patches of Erica is still not clear.

At present, human impact is steadily increasing (Belayneh et al., 2013), despite large areas having been protected within the Bale Mountains National Park since 1970 (Hillman, 1986). During fieldwork in February 2015 and 2017, we observed people in the Bale Mountains mainly subsisting on pastoralism and illegal logging, thus increasingly placing the natural resources and wildlife under immense pressure, leading to deforestation, overgrazing and frequent fire occurrence. Wildfires have likely been a common phenomenon in the Bale Mountains for a long time. However, they seem to have become more severe in recent years (Johansson, 2013).

During the past decades the analyses of stable carbon $\left(\delta^{13} \mathrm{C}\right)$ and nitrogen $\left(\delta^{15} \mathrm{~N}\right)$ isotopes have significantly contributed to a better understanding of (paleo-)ecological processes (Tiunov, 2007). This technique has high potential for tracing biogeochemical processes and for reconstructing past and current interactions between humans, plants and the surrounding environment (Dawson et al., 2002; Zech, 2006; Zech et al., 2011a). Furthermore, $\delta^{13} \mathrm{C}$ analyses of soils and sediments are particularly used to reconstruct alpine vegetation changes in terms of $\mathrm{C}_{3}$ versus $\mathrm{C}_{4}$ photosynthetic pathway (Glaser and Zech, 2005; Zech et al., 2011b). Stable isotopes have been previously used in Ethiopia for reconstructing vegetation history (Gebru et al., 2009; Levin et al., 2011) and to infer land use and land cover change (Eshetu and Högberg, 2000; Liu et al., 2007; Solomon et al., 2002) as well as physiological processes (Krepkowski et al., 2013). Gebru et al. (2009) found that the vegetation has changed from $C_{3}$ to $\mathrm{C}_{4}$ during the late Holocene ( 3300 years BP) in Tigray due to agricultural expansion. Eshetu and Högberg (2000) suggested that the vegetation shifted from grassland to forest in the Menagesha forest and Wendo Genet areas several hundred years ago.
Given that pollen preservation is often poor in soils due to oxidation (Brewer et al., 2013; Hevly, 1981; Li et al., 2007) there have been large efforts during the last decades toward developing proxies based on organic molecules that are specific to certain plant and vegetation types (chemotaxonomy) in order to contribute to the reconstruction of vegetation changes. This is mostly done with lipid biomarkers (Jansen et al., 2006a, b, 2008; see our companion paper, Lemma et al., 2019a, for further details). In addition, Kebede et al. (2007) have used amplified fragment length polymorphisms (AFLPs) to infer the phylogeographical history of the afromontane species (Lobelia giberroa) in the Bale Mountains. Sugar monomers build up polysaccharides such as cellulose and hemicellulose (Simoneit, 2002). While arabinose and xylose are very abundant in plants, fucose and rhamnose are important components of bacterial cell walls. Fucose and rhamnose are therefore often used as proxies for microbe-derived organic matter in soils (Sauheitl et al., 2005). Moreover, sugar biomarkers were proposed and applied as proxies for paleovegetation reconstructions (Glaser and Zech, 2005; Prietzel et al., 2013). For instance, Jia et al. (2008) could chemotaxonomically distinguish between lichens, Sphagnum and vascular plants based on the ratio (mannose + galactose) / (arabinose + xylose) and percentage of (rhamnose + fucose). Similarly, Hepp et al. (2016) suggested the sugar ratios fucose /(arabinose + xylose) and (fucose + xylose) / arabinose as proxies in paleolimnological studies for distinguishing between terrestrial versus aquatic sedimentary organic matter.

The objectives of this study were to evaluate (i) whether the dominant plant and vegetation types of the afroalpine region of the Bale Mountains can be distinguished chemotaxonomically based on their stable carbon and nitrogen isotopic composition and/or sugar biomarkers and (ii) whether the isotope and biomarker patterns of plants are reflected in the soils below correspond to contemporary plants. Note that in our companion paper (Lemma et al., 2019a) we address the same questions but instead focusing on other biomarkers, namely lignin-derived phenols and leaf-wax-derived $n$ alkanes. Overall the results of our two companion studies were meant to form a modern-day calibration for reconstructing the Late Quaternary vegetation history (mainly of Erica) on the Sanetti Plateau of the Bale Mountains.

\section{Material and methods}

\subsection{Study site}

The study was conducted in the Bale Mountains National Park, located in the Oromia Region of Ethiopia (Fig. 1) between $6^{\circ} 40^{\prime}$ and $7^{\circ} 10^{\prime} \mathrm{N}$ and $39^{\circ} 30^{\prime}$ and $39^{\circ} 58^{\prime} \mathrm{E}$ (Miehe and Miehe, 1994, Tiercelin et al., 2008; Umer et al., 2007). It covers an area of $2200 \mathrm{~km}^{2}$ and an altitudinal range from 1400 to $4377 \mathrm{~m}$ a.s.l., including the second highest peak in the country (Tullu Dimtu). The intertropical convergence 


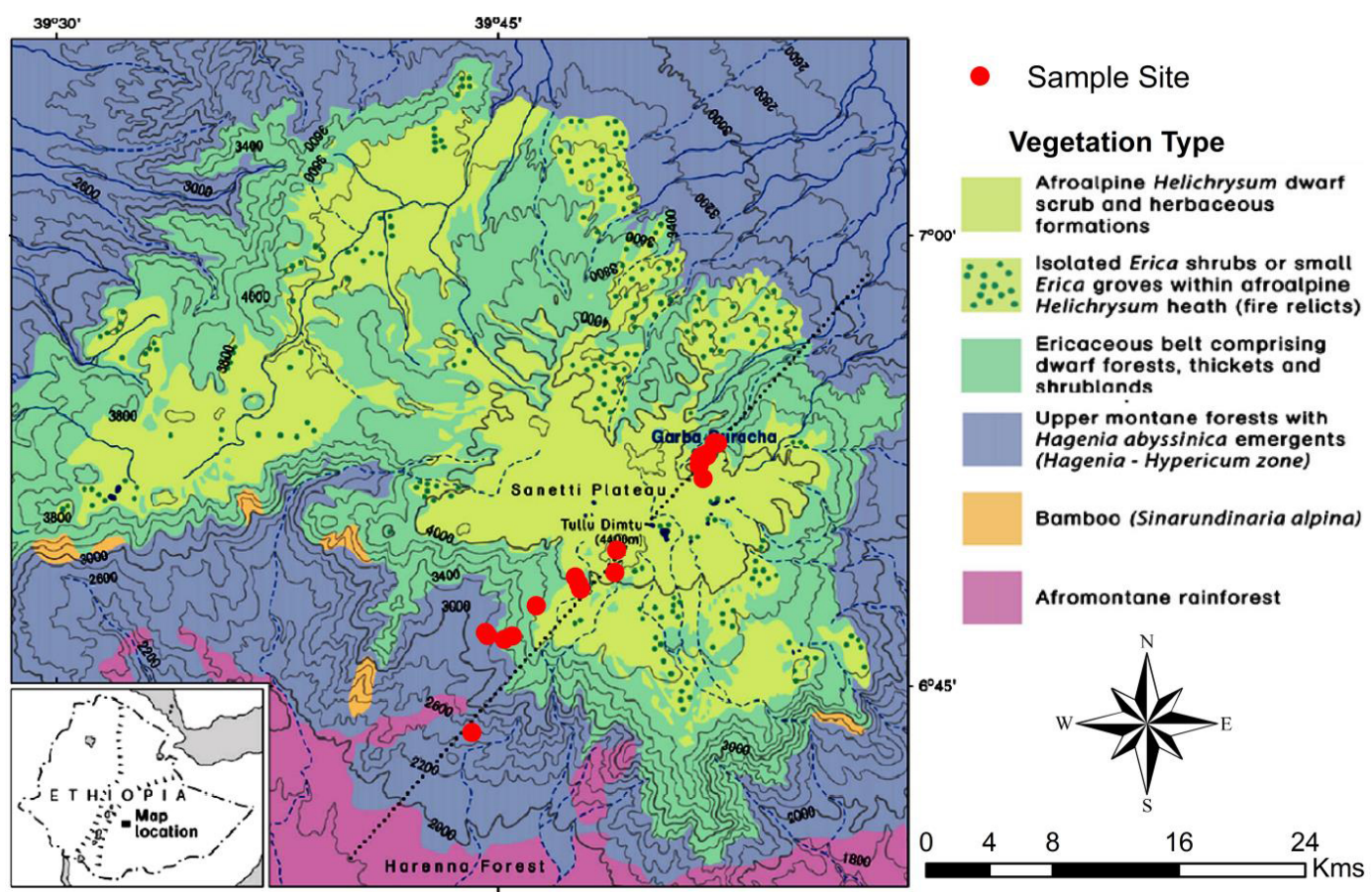

Figure 1. Map of the Bale Mountains showing the vegetation zones and study sites along the northeastern-southwestern transect (modified from Miehe and Miehe, 1994). Dominant vegetation types sampled comprise the Ericaceous and afroalpine belt.

zone (ITCZ), altitudinal and topographic features are the major factors influencing precipitation in the Bale Mountains (Miehe and Miehe, 1994; Bonnefille, 1983). Most of the year, the Bale Mountains are strongly influenced by southeasterlies originating from the Indian Ocean that provide monsoonal precipitation. A recent study done by Lemma et al. (2019b) suggested that the Bale Mountains receive precipitation from the Arabian Sea and southern Indian Ocean during the dry and wet season, respectively. The area experiences two rainy seasons: one lasting from March to June and a second heavy rainy season from July to October. In Dinsho (the Bale Mountains National Park headquarters at $3070 \mathrm{~m}$ a.s.1.), mean annual precipitation is $1069 \mathrm{~mm}$ and mean annual temperature is $11.8^{\circ} \mathrm{C}$. Monthly mean maximum and minimum temperatures are 19.9 and $3.4^{\circ} \mathrm{C}$, respectively (Ethiopian Metrological Services Agency, 20042015). Kidane et al. (2012) emphasized, however, that the mountains experience a highly variable climate from north to south as a result of altitudinal difference and the influence of lowland hot air masses. Extreme temperature variation between the wet and dry seasons is a common phenomenon on the Sanetti Plateau.

The afromontane forest of the Bale Mountains is divided into a southern declivity, or zonation of Harenna forest (1450 to $3200 \mathrm{~m}$ a.s.l. to the southwest), and northern declivity (drier montane forest 2200 to $3750 \mathrm{~m}$ a.s.l.). These vegetation zones are dominated by Podocarpus falcatus, Warburgia ugandensis, Pouteria adolfi-friederici, Cro- ton macrostachyus, Juniperus procera, Hagenia abyssinica and Hypericum revolutum (Friis, 1986; Lisanework and Mesfin, 1989; Yineger et al., 2008). Regions above 3500 m.a.s.l., including the tree line ecotone in eastern Africa, which is comprised of a number of taxa with small sclerophyllous leaves, are characterized as Ericaceous vegetation (Miehe and Miehe, 1994). This vegetation is commonly found on most African mountains, especially in the Atlas Range in North Africa, the Tibesti Mountains of the central Sahara, the Ethiopian Highlands and in the mountains of eastern Africa that extend southwards to Malawi (Jacob et al., 2015; Messerli and Winiger, 1992). This vegetation zone stretches from 3500 to $3800 \mathrm{~m}$ a.s.l. and it becomes patchy on the Sanetti Plateau above $3800 \mathrm{~m}$ a.s.l.. It is continuously dominated by shrubs and shrubby trees such as Erica arborea, Erica trimera, Hypericum revolutum and perennial shrubs or herbs such as Alchemilla haumannii, Anthemis tigreensis, Helichrysum citrispinum, H. splendidum, H. gofense, Senecio schultzii, Thymus schimperi and Kniphofia foliosa (Friis et al., 2010). Some of these species are also found in the afroalpine belt, since the upper and lower boundaries of this belt are very difficult to define. The afroalpine vegetation, which extends from 3800 to $4377 \mathrm{~m}$ a.s.l., is more open and richer in grass. It is mainly characterized by a combination of giant Lobelia (Lobelia rhynchopetalum), species of Helichrysum, shrubby species of Alchemilla, grasses (Festuca richardii, Agrostis quinqueseta and Pentaschistis pictigluma) and the creeping dwarf shrub Euryops prostata. 
The soils in the Bale Mountains National Park are often shallow, rich in stones and with organic layers (O layers), mineral topsoils ( $A_{h}$ horizons), mineral subsoils (B horizons) and parent material (C horizons). Some soils are clearly stratified with bolder rich surface layers $(\mathrm{O}, \mathrm{A}, \mathrm{B})$ above fine textured ash layers $(2 \mathrm{C})$. They are derived from volcanic materials such as lava of various kinds, basalt and agglomerates (Miehe and Miehe 1994) and can be classified as Andosols, Cambisols and Leptosols (Abbate et al., 2015; Billi, 2015; Yimer et al., 2006). In addition, Gleysols and Histosols occur frequently in depressions.

\subsection{Sample collection}

Leaf and soil samples were collected along a northeast (3870 to $4134 \mathrm{~m}$ a.s.1.) to southwest ( 2550 to $4377 \mathrm{~m}$ a.s.1.) transect (Fig. 1). Leaf samples were taken from dominant plants comprising: Erica arborea L. $(n=5)$, Erica trimera (Engl.) Beentje $(n=5)$, Alchemilla haumannii Rothm $(n=$ 5), Helichrysum splendidum Thunb. L. $(n=2)$, Lobelia rhynchopetalum Hemsl. ( $n=1)$, Kniphofia foliosa Hochst. $(n=1)$ and Festuca abyssinica Hochst. ex A. Rich. $(n=6)$ (Fig. 2). Erica leaves were collected from the upper part of the crown. Moreover, 23 mineral topsoils ( $A_{h}$ horizons) from each sampling site were collected in order to test whether these horizons represent the typical biogeochemical features of the standing vegetation. Additionally, where available, humified organic layers (O layers) excluding litter were sampled $(n=15)$.

\subsection{Sample analyses}

Soil samples were air dried and sieved $(<2 \mathrm{~mm})$. An aliquot of plant and soil samples was ground using a ball mill and weighted into separate tin capsules. Total organic carbon (TOC), total nitrogen (TN), and the natural abundance of ${ }^{13} \mathrm{C}$ and ${ }^{15} \mathrm{~N}$ of the samples were measured using an elemental analyzer coupled to an isotope ratio mass spectrometer (EAIRMS). Samples were converted into $\mathrm{CO}_{2}$ and $\mathrm{NO}_{2}$ by an oxidation reactor filled with tungsten trioxide and aluminum oxide and cobalt (II, III) oxide (silvered) $\left(1020^{\circ} \mathrm{C}\right)$. Subsequently, $\mathrm{NO}_{2}$ was further reduced to $\mathrm{N}_{2}$ by a reduction reactor filled with copper wires $\left(650^{\circ} \mathrm{C}\right)$. Water was removed by a magnesium perchlorate trap. Helium (purity $99.9997 \%$ ) was used as carrier gas at $100 \mathrm{~mL} \mathrm{~min}^{-1}$. The precision of the stable isotope analyses as determined by replication measurements of standards was $0.3 \%$ and $0.2 \%$ for $\delta^{13} \mathrm{C}$ and $\delta^{15} \mathrm{~N}$, respectively.

Sugar monomers in the plant and soil samples were extracted hydrolytically with $10 \mathrm{~mL} 4 \mathrm{M}$ trifluoroacetic acid (TFA) and $100 \mu \mathrm{g}$ of myo-inositol (as internal standard) for $4 \mathrm{~h}$ at $105^{\circ} \mathrm{C}$, following the method described by Zech and Glaser (2009). This extraction procedure does not liberate considerable amounts of monosaccharides from cellulose (Amelung et al., 1996). Therefore, this fraction is sometimes called "non-cellulosic polysaccharides" (NCP) in the literature (e.g., Prietzel et al., 2013). The hydrolyzed samples were filtered through a vacuum suction system and the filtrates were collected in $100 \mathrm{~mL}$ conical flasks. The filtrates were then evaporated using rotary evaporators in order to remove the acid and the water that were added to the samples. In order to remove humic substances and cations, the redissolved samples were passed through XAD and Dowex resin columns, respectively, following Amelung et al. (1996), and the filtrates were collected in $50 \mathrm{~mL}$ conical flasks. The filtrates were dried using rotary evaporators and a freeze drier. The purified neutral sugars were transferred into ReactiVials. Derivatization of the freeze-dried sugars was done with N-methyl-2-pyrrolidone (NMP) at $75^{\circ} \mathrm{C}$ for $30 \mathrm{~min}$ in a heating block. After cooling, $400 \mu \mathrm{L}$ of BSTFA (N, OBis(trimethylsilyl)trifluoracetamide) were added to the vials and the samples were heated again to $75^{\circ} \mathrm{C}$ for $5 \mathrm{~min}$. The samples were transferred to auto-sampler vials after cooling and measured using gas chromatography (SHIMADZU GC-2010, Kyoto, Japan) equipped with a flame ionization detector (FID). Sugars were separated on a Supelco SPB-5 column (length, $30 \mathrm{~m}$; inner diameter, $0.25 \mathrm{~mm}$; film thickness, $0.25 \mu \mathrm{m}$ ) using helium as carrier gas. The temperature was ramped from 160 to $185^{\circ} \mathrm{C}$, held for $4 \mathrm{~min}$, then ramped to $240^{\circ} \mathrm{C}$ and held for $0 \mathrm{~min}$, and finally ramped to $300^{\circ} \mathrm{C}$ and held for $5 \mathrm{~min}$. The temperature of the injector was set at $250{ }^{\circ} \mathrm{C}$. Hierarchical cluster analysis and notch box plots for the sugar biomarkers data were done by using the R software (version 3.4.4, 15 March 2018).

\section{Results and discussion}

\subsection{Elemental composition, $\delta^{13} \mathrm{C}$ and $\delta^{15} \mathrm{~N}$ of dominant plants}

Total organic carbon and nitrogen contents were used to calculate TOC / TN ratios in order to characterize and possibly distinguish the investigated plant types. The leaf samples yielded values covering a wide range from 14.5 ( $\mathrm{Lo}$ belia) to 80.4 (Erica). The boxplot diagrams in Fig. 3a depict that plant leaves are characterized by significantly higher TOC / TN ratios compared to corresponding O layers and $\mathrm{A}_{\mathrm{h}}$ horizons. Mean TOC / TN values for all investigated dominant plants are $>40$, thus confirming the finding of Zech (2006) and Zech et al. (2011b) from Mt. Kilimanjaro that subalpine and alpine vegetation has typically very high TOC / TN values.

The $\delta^{13} \mathrm{C}$ values of Erica are not significantly different from the other plants (Fig. 3b). Note that Kniphofia has a more positive value, but a statistical comparison could not be applied because only one sample is available. No significant variation in stable isotopes among the rest of dominant plant species could be detected either. Overall, the $\delta^{13} \mathrm{C}$ values of all investigated plants range from -27.5 (Erica) to $-23.9 \%$ (Kniphofia); thus, they are well within the typical 
(a)

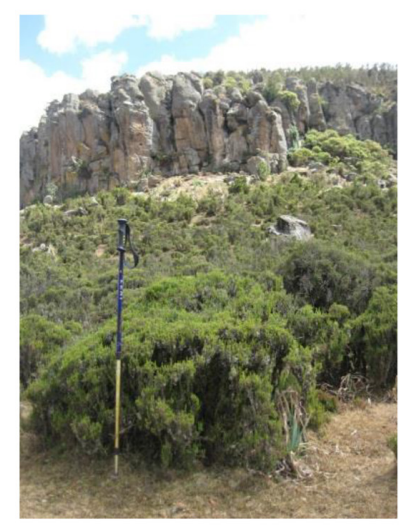

(d)

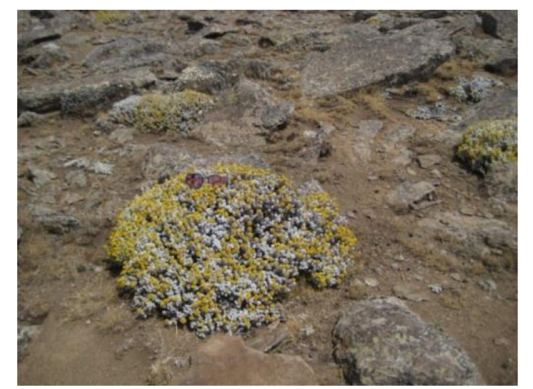

(b)

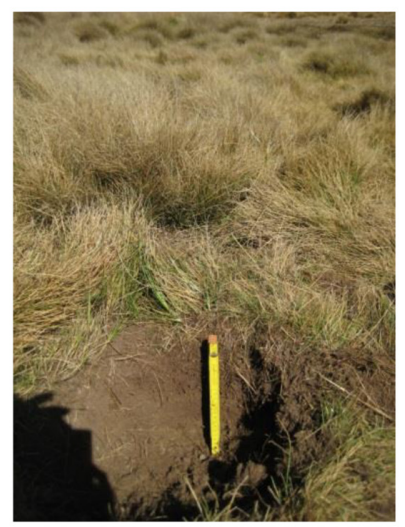

(e)

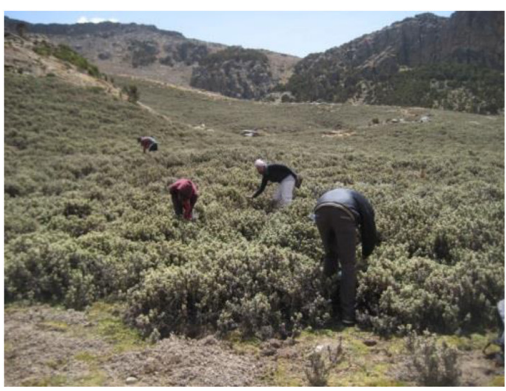

(c)

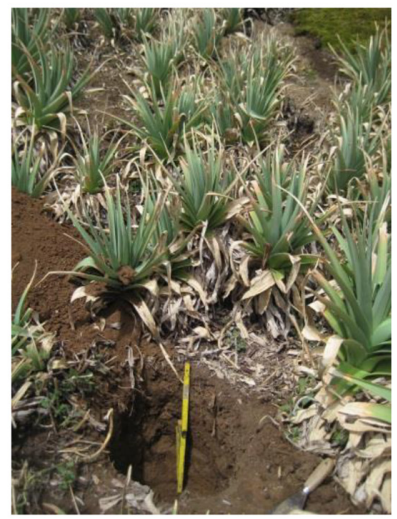

(f)

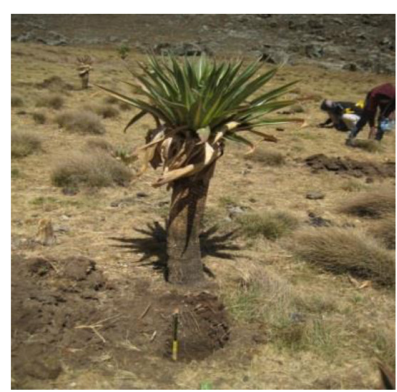

Figure 2. Photos showing plant species investigated in this study: (a) Erica trimera (3870 m a.s.1.), (b) Festuca abyssinica (3920 m a.s.1.), (c) Alchemilla haumannii (3947 m a.s.1.), (d) Helichrysum splendidum (4377 m a.s.1.), (e) Kniphofia Foliosa (3930 m a.s.1.) and (f) Lobelia rhynchopetalum (3922 $\mathrm{m}$ a.s.1.).

range for $\mathrm{C}_{3}$ plants. The occurrence of (sub)alpine $\mathrm{C}_{4}$ plants similar to those on Mt. Kenya (Street-Perrott et al., 2004; Young and Young, 1983) is hitherto not confirmed for the Bale Mountains based on the admittedly quite limited plant sample set presented here. However, the absence of $\mathrm{C}_{4}$ would be in agreement with the findings of Zech et al. (2011b) from Mt. Kilimanjaro. Furthermore, our $\delta^{13} \mathrm{C}$ leaf data do not reveal a dependence on altitude, as reported by Körner et al. (1991) for a global dataset. This likely reflects that local climatic conditions and other factors exert a higher control in our study area. The $\delta^{15} \mathrm{~N}$ values for leaf material range from -4.8 (Erica) to $5.1 \%$ (Alchemilla). Such a relatively large $\delta^{15} \mathrm{~N}$ variability is well described for plants and can be explained by different nitrogen sources being taken up and by different mechanisms of $\mathrm{N}$ uptake including mycorrhizae being present. Similar to the $\delta^{13} \mathrm{C}$ results, $\delta^{15} \mathrm{~N}$ values of Erica are not significantly different from other plants (Fig. 3c).

\subsection{Elemental composition, $\delta^{13} \mathrm{C}$ and $\delta^{15} \mathrm{~N}$ in O layers and $A_{h}$ horizons}

Apart from revealing similarities and/or differences in TOC / TN, $\delta^{13} \mathrm{C}$ and $\delta^{15} \mathrm{~N}$ between the dominant plants, Fig. 3a furthermore reveals that TOC / TN ratios generally strongly decrease from leaf material over $\mathrm{O}$ layers to the respective $A_{h}$ horizons. This reflects the preferential loss of carbon versus nitrogen during mineralization (Meyers, 1994). At the same time, this decrease implies that TOC / TN ratios of plants cannot be used as a straight-forward proxy for paleovegetation reconstructions in archives that are prone to organic matter degradation and mineralization.

According to Fig. 3b, the O layers tend to have slightly more negative $\delta^{13} \mathrm{C}$ values compared to leaf material. By contrast, $\mathrm{A}_{\mathrm{h}}$ horizons have generally more positive $\delta^{13} \mathrm{C}$ values. We explain the former finding with the preferential loss of an easily degradable ${ }^{13} \mathrm{C}$-enriched organic matter pool, like sugars during a very early stage of leaf litter degradation. The later finding is in agreement with numerous studies (Ehleringer et al., 2000; Garten et al., 2000; Natelhoffer and Fry, 1988) reporting on increasing $\delta^{13} \mathrm{C}$ values with increasing soil depths. This ${ }^{13} \mathrm{C}$ enrichment in soils is usually explained by the preferential enzymatically controlled loss of ${ }^{12} \mathrm{C}$ during soil organic matter degradation (Farquhar et al., 1982; Friedli et al., 1986; Zech et al., 2007). It may be noteworthy that two $A_{h}$ horizons of the northeastern part of the transect yielded very positive $\delta^{13} \mathrm{C}$ values of $-21.2 \%$ and $-19.1 \%$, respectively, which are higher than expected for 
(a)

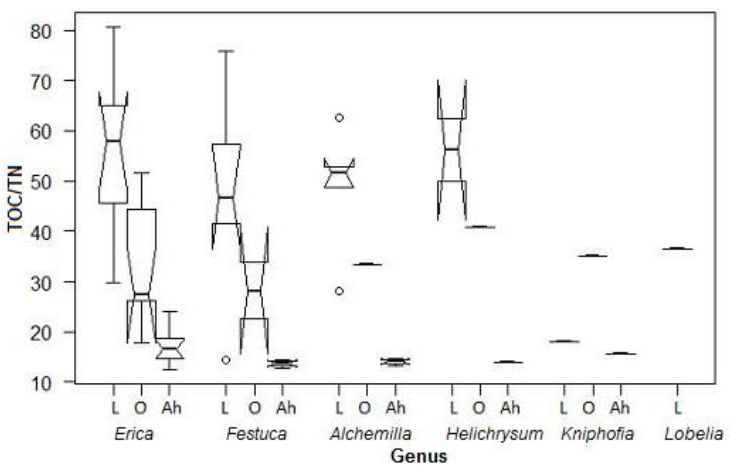

(b)

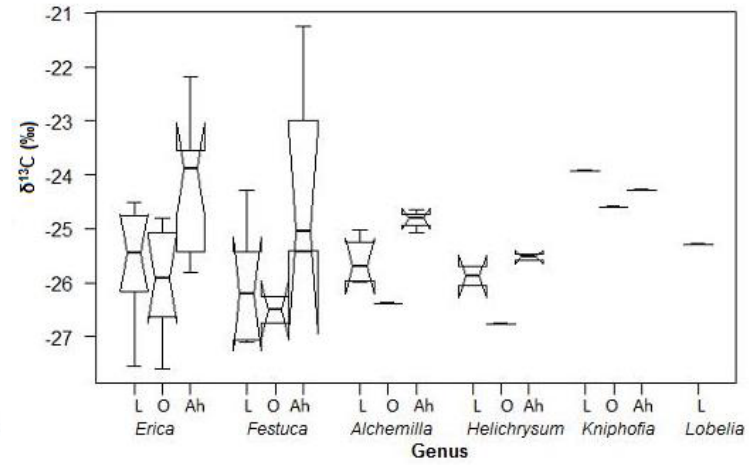

(c)

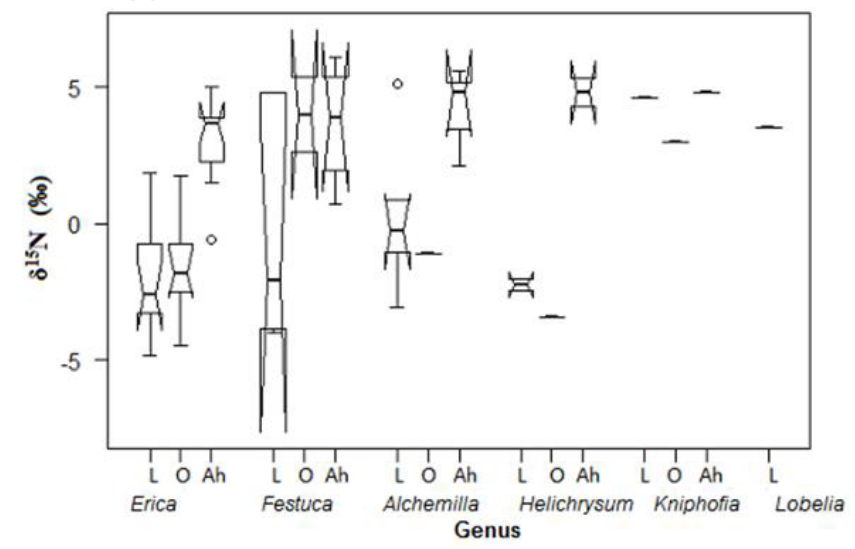

Figure 3. Boxplot diagrams showing (a) TOC / TN and (b) $\delta^{13} \mathrm{C}$ and (c) $\delta^{15} \mathrm{~N}$ results for leaves (L), O layers and $\mathrm{A}_{\mathrm{h}}$ horizons of the investigated dominant vegetation types in the Bale Mountains. The upper and lower bold lines indicate the 75th and 25th quartiles, respectively, and the middle bold line shows the median. The lines extending outside the box (whiskers) show variability outside the quartiles and notches indicate the $95 \%$ confidence interval. White circles represent outliers. Note that short horizontal single lines are due to small sample sizes.

soils that have developed under pure $\mathrm{C}_{3}$ vegetation. Given that our plant sample set is rather small, it cannot be excluded that those soils received litter from $\mathrm{C}_{4}$ grasses and we encourage further studies in order to clarify whether $\mathrm{C}_{4}$ grasses occur in the Bale Mountains like on Mt. Kenya or not (see Sect. 3.1).

Like $\delta^{13} \mathrm{C}, \delta^{15} \mathrm{~N}$ of soils is also reported to be strongly affected by soil organic matter degradation and mineralization (Natelhoffer and Fry, 1988; Zech et al., 2007). It is hence not surprising that the investigated $A_{h}$ horizons are clearly ${ }^{15} \mathrm{~N}$-enriched compared to the leaf samples (Fig. 3c). Furthermore, the $\mathrm{O}$ layers and the $\mathrm{A}_{\mathrm{h}}$ horizons across the altitudinal transects of the Bale Mountains reveal a general trend toward more negative values with increasing altitude (Fig. 4). Similar findings were reported for the southern and northern slopes of Mt. Kilimanjaro (Zech et al., 2011a, b) and reflect that the $\mathrm{N}$ cycle is open at lower altitudes as it is characterized by higher temperatures. By contrast, at higher altitudes $\mathrm{N}$ mineralization and $\mathrm{N}$ losses are reduced (closed $\mathrm{N}$ cycle) due to lower temperatures. As an exception from this over- all trend, the $\mathrm{O}$ layers reveal a maximum between 3920 and $3950 \mathrm{~m}$ a.s.l. and the $\mathrm{A}_{\mathrm{h}}$ horizons reveal two maxima around 3950 as well as around $4130 \mathrm{~m}$ a.s.l. Given that $\mathrm{O}$ layers and $\mathrm{A}_{\mathrm{h}}$ horizons act as integrated recorders of the $\mathrm{N}$ cycle taken from periods of several years and hundreds of years, respectively, those maxima indicate that at the respective sampling sites the $\mathrm{N}$ cycle was open and significant $\mathrm{N}$ losses occurred during the past. Several studies emphasized already that the subalpine and alpine zones in the Bale Mountains are heavily affected by human-induced fires (Johansson, 2013; Kidane et al., 2012; Miehe and Miehe,1994; and Wesche et al., 2000). Therefore, we attribute this opening of the $\mathrm{N}$ cycle to the repeated burning (and thus loss) of the relatively ${ }^{15} \mathrm{~N}$-depleted vegetation cover.

\subsection{Sugar concentrations and patterns of dominant plants}

As shown in Fig. 5, the overall non-cellulosic sugar concentrations in leaves range from 58 to $253 \mathrm{mg} \mathrm{g}^{-1}$. We found high contents in Festuca and Alchemilla, whereas Erica is 


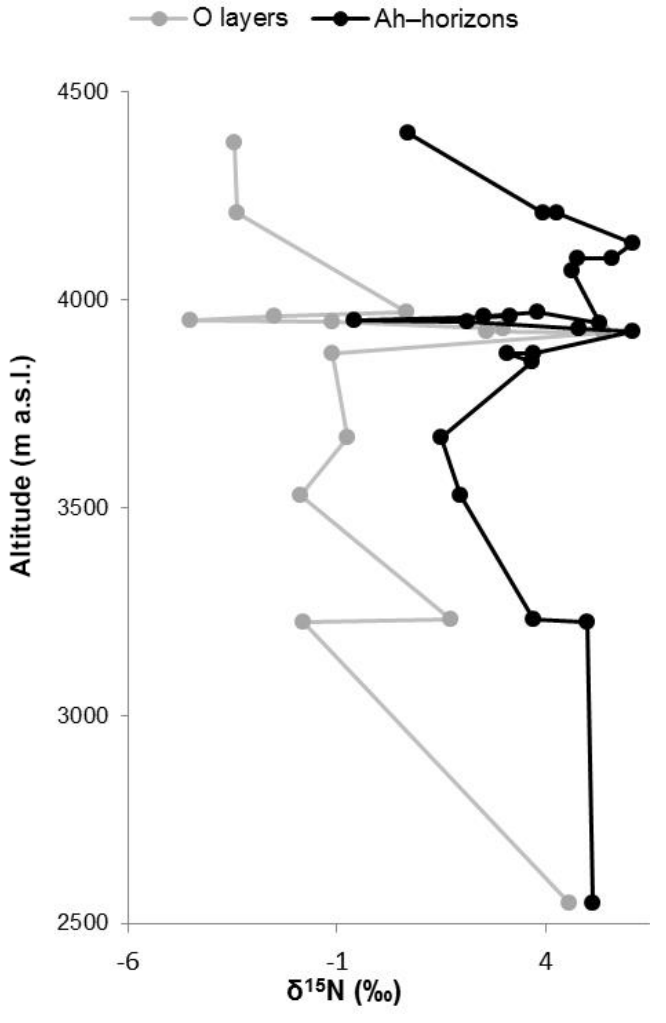

Figure 4. $\delta^{15} \mathrm{~N}$ results of $\mathrm{O}$ layers and $\mathrm{A}_{\mathrm{h}}$ horizons along altitudinal transects of the Bale Mountains.

characterized by relatively low non-cellulosic sugar concentrations. This has implications for paleovegetation reconstructions because plants producing lower amounts of sugars are less represented in soils and sedimentary archives. A comparable example for such an issue is leaf-wax-derived $n$ alkane biomarkers not being sensitive enough for coniferous trees due to the very low $n$-alkane concentrations of coniferous needles (Zech et al., 2012).

Nevertheless, a hierarchical cluster analysis performed for leaves on the basis of their individual sugar monomers arabinose, fucose, galactose, mannose, rhamnose, ribose, xylose, glucuronic acid and galacturonic acid resulted in three main groups, suggesting that a chemotaxonomic differentiation of the dominant vegetation types on the Bale Mountains may be possible (Fig. 6). The first group mainly represents Kniphofia, Alchemilla and Helicrysum species indicating close similarity between them. The second group predominantly contains Erica spp. and the third group is mainly composed of Festuca spp. This result allows the conclusion that the plant species under study vary in their foliar sugar composition. Erica and Festuca vary especially clearly in their sugar signatures.

Both Jia et al. (2008) and Prietzel et al. (2013) used the ratio of galactose and mannose versus arabinose and $x y-$ lose $((\mathrm{G}+\mathrm{M}) /(\mathrm{A}+\mathrm{X}))$ in particular, in order to distinguish between different vegetation types. In the Bale Mountains,

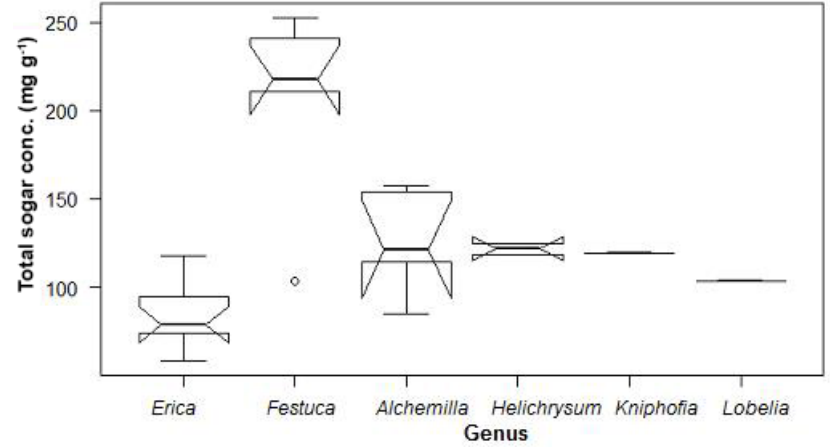

Figure 5. Total sugar concentrations of the investigated plant leaves along altitudinal transects of the Bale Mountains. The upper and lower bold lines indicate 75 th and 25th quartiles, respectively, and the middle bold line shows the median. The lines extending outside the box (whiskers) show variability outside the quartiles and notches indicate the $95 \%$ confidence interval. White circles represent outliers. Note that short horizontal single lines are due to small sample sizes.

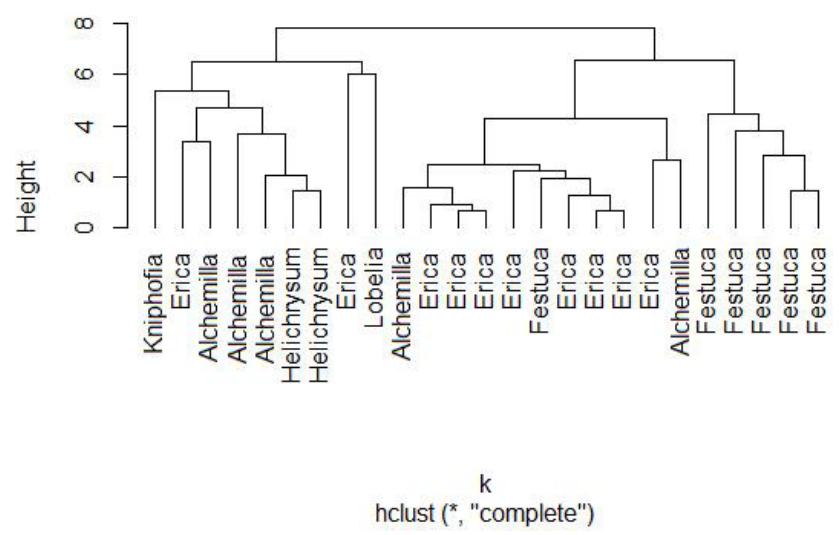

Figure 6. Cluster formation based on non-cellulosic sugar biomarker concentrations of leaf samples from the dominant vegetation types in the Bale Mountains.

Erica leaves yielded significantly higher $(\mathrm{G}+\mathrm{M}) /(\mathrm{A}+\mathrm{X})$ ratios compared to Alchemilla, Festuca and Helichrysum (Fig. 7a). Hence, one might be tempted to recommend the $(\mathrm{G}+\mathrm{M}) /(\mathrm{A}+\mathrm{X})$ ratio as a proxy in soils and sediments for reconstructing Erica distribution during the past. Note that the $(\mathrm{G}+\mathrm{M}) /(\mathrm{A}+\mathrm{X})$ ratios around 1 for Erica, Kniphofia and Lobelia are clearly higher than the ratios reported to be typical for plants according to Oades (1984). By contrast, the fucose to arabinose and xylose ratios $(\mathrm{F} /(\mathrm{A}+\mathrm{X}))$ are very low, as expected for plants (cf. Hepp et al., 2016), with a mean value of $0.05 \pm 0.05(n=25)$. Erica is characterized by higher ratios than Festuca (Fig. 7b).

\subsection{Sugar patterns of $\mathrm{O}$ layers and $\mathrm{A}_{h}$ horizons}

The characteristic $(\mathrm{G}+\mathrm{M}) /(\mathrm{A}+\mathrm{X})$ and $\mathrm{F} /(\mathrm{A}+\mathrm{X})$ ratios for the dominant vegetation types are not well reflected in 
(a)

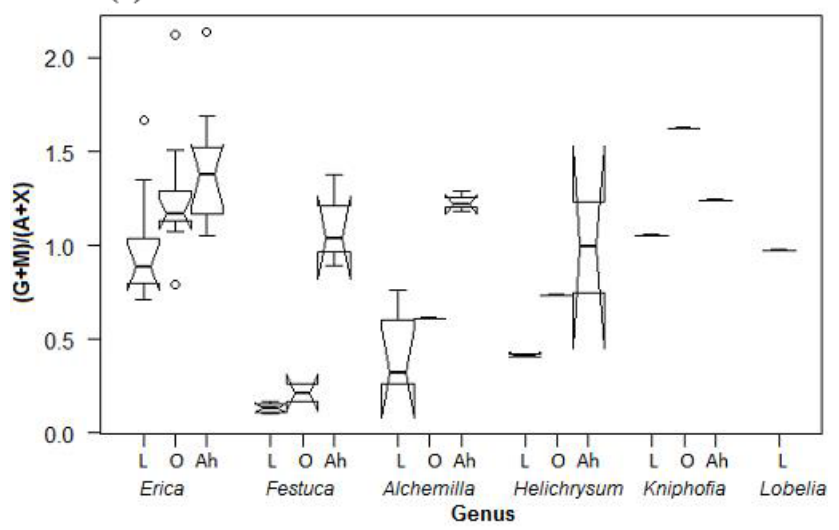

(b)

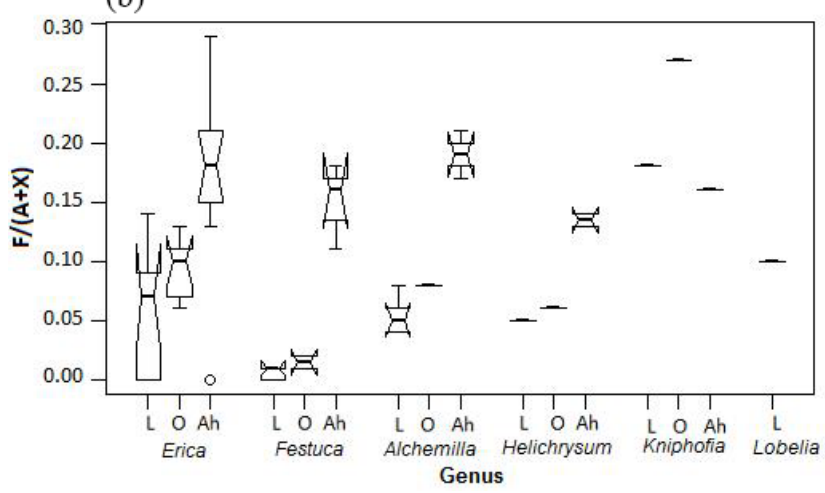

Figure 7. Boxplot diagram showing the (a) $(\mathrm{G}+\mathrm{M}) /(\mathrm{A}+\mathrm{X})$ and (b) $\mathrm{F} /(\mathrm{A}+\mathrm{X})$ ratios of leaves $(\mathrm{L})$, $\mathrm{O}$ layers and $\mathrm{A}_{\mathrm{h}}$ horizons, respectively, along the altitudinal transect across the Bale Mountains. The upper and lower bold lines indicate 75th and 25th quartiles, respectively, and the middle bold line shows the median. The lines extending outside the box (whiskers) show variability outside the quartiles and notches indicate the $95 \%$ confidence interval. White circles represent outliers. Note that short horizontal single lines are due to small sample sizes.

the respective $O$ layers and $A_{h}$ horizons (Fig. 7). Rather, the ratios generally increase, indicating that both arabinose and xylose are preferentially degraded or that galactose, mannose and fucose are built-up by soil microorganisms. This later interpretation is in agreement with Oades (1984), who reported that soil microorganisms are characterized by $(\mathrm{G}+\mathrm{M}) /(\mathrm{A}+\mathrm{X})$ ratios $>2$. The $\mathrm{F} /(\mathrm{A}+\mathrm{X})$ ratios of $0.18 \pm 0.07$ observed for $A_{h}$ horizons in this study are well within the range reported for terrestrial soils by Hepp et al. (2016). Apart from soil microorganisms, a considerable contribution of root-derived sugars, including root exudates, is very likely as well (Gunina and Kuzyakov, 2015). More systematic respective biomarker studies, similar to, for instance, the one carried out by Prietzel et al. (2013) are therefore encouraged in order to address this effect more quantitatively in the future.

As a result, soils under Alchemilla and Festuca yield $(\mathrm{G}+\mathrm{M}) /(\mathrm{A}+\mathrm{X})$ ratios similar to those of Erica leaves.
This has severe implications for paleovegetation reconstructions based on sugar biomarkers and resembles degradation problems reported for lignin-derived phenol and leaf-waxderived $n$-alkane biomarkers (Lemma et al., 2019a; Zech et al., 2012). In the case of the Bale Mountains, only fresh leaves or leaf material that has undergone little degradation (as it may hold true in anoxic lacustrine sediments) allow a chemotaxonomic differentiation between Erica and other dominant vegetation types, such as Alchemilla, Festuca and Helichrysum. Given that by contrast good preservation of sugar biomarkers is usually not the case in soils, we consider neutral sugar biomarkers unsuitable for reconstructing former Erica expansion from paleosols in our study area and instead encourage studies focusing on other biomarkers.

\section{Conclusions}

Having investigated plant material, $\mathrm{O}$ layers and $\mathrm{A}_{h}$ horizons along altitudinal transects, we found no clear evidence for the modern-day occurrence of $\mathrm{C}_{4}$ grasses in the Bale Mountains. Neither $\delta^{13} \mathrm{C}$ nor $\delta^{15} \mathrm{~N}$ values allow a clear chemotaxonomic differentiation of Erica from other dominant vegetation types such as Alchemilla, Festuca and Helichrysum. TOC / TN ratios strongly decrease and both ${ }^{13} \mathrm{C}$ and ${ }^{15} \mathrm{~N}$ become generally enriched from the leaves to the $\mathrm{A}_{\mathrm{h}}$ horizons due to degradation and mineralization. $\delta^{15} \mathrm{~N}$ is furthermore generally more negative at higher altitudes, which reflects a low degree of mineralization and overall a relatively closed $\mathrm{N}$ cycle due to low temperatures. $\delta^{15} \mathrm{~N}$ maxima around $4000 \mathrm{~m}$ a.s.l. indicate the likely fire-induced opening of the $\mathrm{N}$ cycle at the respective study sites. Erica leaves are characterized by relatively low total sugar concentrations and can be chemotaxonomically distinguished from the other dominant vegetation types mainly because of their higher relative amounts of galactose and mannose. However, these sugar monomers are produced by soil microorganisms as well. Therefore, soils under Alchemilla and Festuca yielded $(\mathrm{G}+\mathrm{M}) /(\mathrm{A}+\mathrm{X})$ ratios similar to those of Erica leaves, and even in soils under Erica this ratio significantly increased. This suggests that sugar biomarkers alone do not allow the establishment of a straight-forward proxy for reconstructing the former expansion of Erica on the Sanetti Plateau. Therefore, future work should emphasize alternative promising molecular markers, such as tannin-derived phenols and terpenoids. In addition, black carbon should be analyzed in order to reveal the impact of fire on the extent of the Ericaceous vegetation.

Data availability. The data are archived in the following Zenodo repository: https://doi.org/10.5281/zenodo.3371636, available at: https://zenodo.org/record/3371636\T1\textbackslash\# .XVrf3N4zbIU. 
Author contributions. WZ and BG designed the research. The fieldwork (sample collection) was done by WZ, BM and BL. BM and TB did the laboratory work and BM prepared the manuscript with the help of MZ. All co-authors contributed to, read and approved the manuscript.

Competing interests. The authors declare that they have no conflict of interest.

Acknowledgements. We are grateful to the Bale Mountains National Park, Ethiopian Biodiversity Institute and Ethiopian Wildlife Conservation Authority for permitting the scientific field work and facilitating the access to the plant and soil materials used in this study. We would like to express our gratitude to the Department of Plant Biology and Biodiversity Management at Addis Ababa University for their scientific collaboration. We also extend our sincere thanks to Marianne Benesch for analyzing the stable isotopes and Heike Maennicke for her great help with the sugar analysis. We acknowledge the financial support within the funding program Open Access Publishing by the German Research Foundation (DFG). Last, but not least, Betelhem Mekonnen acknowledges the support given by the Katholischer Akademischer Ausländer-Dienst (KAAD). We kindly thank three anonymous reviewers for their constructive comments and suggestions that greatly helped to improve our manuscript.

Financial support. This research has been supported by the DFG (grant nos. GL327/18-1, ZE844/10-1).

\section{References}

Abbate, E., Bruni, P., and Sagri, M.: Geology of Ethiopia: A Review and Geomorphological Perspectives, in: Landscapes and Landforms of Ethiopia, edited by: Billi, P., Springer Netherlands, Dordrecht, 33-64, 2015.

Amelung, W., Cheshire, M. V., and Guggenberger, G.: Determination of neutral and acidic sugars in soil by capillary gas liquid chromatography after trifluoroacetic acid hydrolysis, Soil Biol. Biochem., 28, 1631-1639, https://doi.org/10.1016/S00380717(96)00248-9, 1996.

Belayneh, A., Yohannes, T., and Worku, A.: Recurrent and extensive forest fire incidence in the Bale Mountains National Park (BMNP), Ethiopia: Extent, Cause and Consequences, Int. J. Environ. Sci., 2, 29-39, 2013.

Billi, P.: Geomorphological Landscapes of Ethiopia, in Landscapes and Landforms of Ethiopia, edited by: Billi, P., 3-32, Springer Netherlands, Dordrecht, 2015.

Bonnefille, R.: Evidence for a Cooler and Drier Climate in Ethiopia 2.5 Mys, Nature, 303, 487-491, 1983.

Bonnefille, R. and Hamilton, C.: Quaternary and Late Tertiary history of Ethiopian vegetation, Acta Uni. Upps. Symb. Bot. Upps. 26, 48-63, 1986.

Brewer, S., Guiot, J., and Barboni, D.: Use of Pollen as Climate Proxies, Encycl. Quat. Sci. Second Ed., 805-815, https://doi.org/10.1016/B978-0-444-53643-3.00180-1, 2013.
Dawson, T. E., Mambelli, S., Plamboeck, A. H., Templer, P. H., and Tu, K. P.: Stable Isotopes in Plant Ecology, Annu. Rev. Ecol. Syst., 33, 507-559, https://doi.org/10.1146/annurev.ecolsys.33.020602.095451, 2002.

Ehleringer, J. R., Buchmann, N., and Flanagan, L. B.: Carbon isotope ratios in belowground carbon cycle processes, Ecol. Appl., 10, 412-422, 2000.

Eshetu, Z. and Högberg, P.: Reconstruction of Forest Site History in Ethiopian Highlands Based on ${ }^{13} \mathrm{C}$ Natural Abundance of Soils, AMBIO A J. Hum. Environ., 29, 83-89, https://doi.org/10.1579/0044-7447-29.2.83, 2000.

Farquhar, G., O'Leary, and Berry, J.: On the relationship between carbon isotope discrimination and the intercellular carbon dioxide concentration in leaves, Aust. J. Plant Physiol., 9, 121-137, 1982.

Friedli, H., Lötscher, H., Oeschger, H., Siegenthaler, U., and Stauffer, B.: Ice core record of the ${ }^{13} \mathrm{C} /{ }^{12} \mathrm{C}$ ratio of atmospheric $\mathrm{CO}_{2}$ in the past two centuries, Nature, 324, 237-238, https://doi.org/10.1038/324237a0, 1986.

Friis, I.: Zonation of Forest Vegetation on the South Slope of Bale Mountains, South Ethiopia, Ethiop. J. Sci., 9, 29-44, 1986.

Friis, I., Sebsebe, D., and Breugel, P. V.: Atlas of the Potential Vegetation of Ethiopia, The Royal Danish Academy of Sciences and Letters, Addis Ababa University Press and Shama Books, Addis Ababa, Ethiopia, 307 pp., 2010.

Garten, C. T., Cooper, L. W., Post, W. M., and Hanson, P. J.: Climate Controls on Forest Soil C Isotope Ratios in the Southern Appalachian Mountains, Ecology, 81, 1108-1119, 2000.

Gebru, T., Eshetu, Z., Huang, Y., Woldemariam, T., Strong, N., Umer, M., DiBlasi, M., and Terwilliger, V. J.: Holocene palaeovegetation of the Tigray Plateau in northern Ethiopia from charcoal and stable organic carbon isotopic analyses of gully sediments, Palaeogeogr. Palaeocl., 282, 67-80, https://doi.org/10.1016/j.palaeo.2009.08.011, 2009.

Glaser, B. and Zech, W.: Reconstruction of climate and landscape changes in a high mountain lake catchment in the Gorkha Himal, Nepal during the Late Glacial and Holocene as deduced from radiocarbon and compound-specific stable isotope analysis of terrestrial, aquatic and microbial biomarkers, Org. Geochem., 36, 1086-1098, https://doi.org/10.1016/j.orggeochem.2005.01.015, 2005.

Gunina, A. and Kuzyakov, Y.: Soil Biology \& Biochemistry Sugars in soil and sweets for microorganisms: Review of origin, content composition and fate, Soil Biol. Biochem., 90, 87-100, 2015.

Hamilton, A. C.: Environmental history of East Africa, A study of the Quarternary, London, Academic Press, https://doi.org/10.2307/2259986, 328 pp., 1982.

Hedberg, O.: Vegetation belts of the east african mountains, Svenska botaniska fôreningens, Stockholm, 1951.

Hedberg, O.: Evolution and speciation in a tropical high mountain flora, Biol. J. Linn. Soc., 1, 135-148, https://doi.org/10.1111/j.1095-8312.1969.tb01816.x, 1969.

Hepp, J., Rabus, M., Anhäuser, T., Bromm, T., Laforsch, C., Sirocko, F., Glaser, B., and Zech, M.: A sugar biomarker proxy for assessing terrestrial versus aquatic sedimentary input, Org. Geochem., 98, 98-104, https://doi.org/10.1016/j.orggeochem.2016.05.012, 2016. 
Hevly, R. H.: Pollen production, transport and preservation?, Potentials and limitations in archaeological palynology, 39-54, 1981.

Hillman, J. C.: Conservation in Bale Mountains National Park, Ethiopia, Oryx, 20, 89-94, https://doi.org/10.1017/S0030605300026314, 1986.

Jacob, M., Annys, S., Frankl, A., De Ridder, M., Beeckman, H., Guyassa, E. and Nyssen, J.: Tree line dynamics in the tropical African highlands - identifying drivers and dynamics, J. Veg. Sci., 26, 9-20, https://doi.org/10.1111/jvs.12215, 2015.

Jansen, B., Nierop, K. G. J., Kotte, M. C., de Voogt, P., and Verstraten, J. M.: The applicability of accelerated solvent extraction (ASE) to extract lipid biomarkers from soils, Appl. Geochem., 21, 1006-1015, https://doi.org/10.1016/j.apgeochem.2006.02.021, 2006a.

Jansen, B., Nierop, K. G. J., Hageman, J. A., Cleef, A. M., and Verstraten, J. M.: The straight-chain lipid biomarker composition of plant species responsible for the dominant biomass production along two altitudinal transects in the Ecuadorian Andes, Org. Geochem., 37, 1514-1536, https://doi.org/10.1016/j.orggeochem.2006.06.018, 2006b.

Jansen, B., Haussmann, N. S., Tonneijck, F. H., Verstraten, J. M., and de Voogt, P.: Characteristic straight-chain lipid ratios as a quick method to assess past forest-páramo transitions in the Ecuadorian Andes, Palaeogeogr. Palaeocl., 262, 129-139, https://doi.org/10.1016/j.palaeo.2008.02.007, 2008.

Jia, G., Dungait, J. A. J., Bingham, E. M., Valiranta, M., Korhola, A., and Evershed, R. P.: Neutral monosaccharides as biomarker proxies for bog-forming plants for application to palaeovegetation reconstruction in ombrotrophic peat deposits, Org. Geochem., 39, 1790-1799, https://doi.org/10.1016/j.orggeochem, 2008.

Johansson, M.: Fire and grazing in subalpine heathlands and forests of Bale Mountains, Ethiopia, Institutionen för skogens ekologi och skötsel, Sveriges lantbruksuniversitet, Umeå, 14, 16521668, 2013.

Kebede, M., Ehrich, D., Taberlet, P., Nemomissa, S., and Brochmann, C.: Phylogeography and conservation genetics of a giant lobelia (Lobelia giberroa) in Ethiopian and Tropical East African mountains, Mol. Ecol., 16, 1233-1243, https://doi.org/10.1111/j.1365-294X.2007.03232.x, 2007.

Kidane, Y., Stahlmann, R., and Beierkuhnlein, C.: Vegetation dynamics, and land use and land cover change in the Bale Mountains, Ethiopia, Environ. Monit. Assess., 184, 7473-7489, https://doi.org/10.1007/s10661-011-2514-8, 2012.

Körner, C., Farquhar, G. D., and Wong, S. C.: Carbon isotope discrimination by plants follows latitudinal and altitudinal trends, Oecologia, 88, 30-40, https://doi.org/10.1007/BF00328400, 1991.

Krepkowski, J., Gebrekirstos, A., Shibistova, O., and Br, A.: Stable carbon isotope labeling reveals different carry-over effects between functional types of tropical trees in an Ethiopian mountain forest, New Phytol., 199, 431-440, 2013.

Lemma, B., Mekonnen, B., Glaser, B., Zech, W., Nemomissa, S., Bekele, T., Bittner, L., and Zech, M.: Chemotaxonomic patterns of vegetation and soils along altitudinal transects of the Bale Mountains, Ethiopia, and implications for paleovegetation reconstructions - Part II: lignin-derived phenols and leafwax-derived $n$-alkanes, E\&G Quaternary Sci. J., 69, 189-200, https://doi.org/10.5194/egqsj-69-189-2019, 2019a.
Lemma, B., Kebede, S., Nemomissa, S., Otte, I., Glaser, B., and Zech, M.: Spatial and temporal ${ }^{2} \mathrm{H}$ and ${ }^{18} \mathrm{O}$ isotope variation of contemporary precipitation in the Bale Mountains, Ethiopia, Isotopes in Environmental and Health Studies, submitted, $2019 \mathrm{~b}$.

Levin, N. E., Brown, F. H., Behrensmeyer, A. K., Bobe, R., and Cerling, T. E.: Paleosol carbonates from the omo group: Isotopic records of local and regional environmental change in East Africa, Palaeogeogr. Palaeocl., 307, 75-89, https://doi.org/10.1016/j.palaeo.2011.04.026, 2011.

Li, Y. C., Hai, Q., Corresp, X., Yang, X. L., Chen, H., Lu, X. M., Li, Y., Xu, Q., Yang, X., Chen, H. U. I., and Lu, X.: Pollen - vegetation relationship and pollen preservation on the Northeastern Qinghai - Tibetan Plateau, Grana, 44, 160-171, https://doi.org/10.1080/00173130500230608, 2005.

Lisanework, N. and Mesfin, T.: An ecological study of the vegetation of the Harenna forest, Bale, Ethiopia. Ethiop. J. Sci. 12, 63-93, 1989.

Liu, X. H., Zhao, L. J., Gasaw, M., Gao, D. Y., Qin, D. H., and Ren, J. W.: Foliar $\delta^{13} \mathrm{C}$ and $\delta^{15} \mathrm{~N}$ values of $\mathrm{C}_{3}$ plants in the Ethiopia Rift Valley and their environmental controls, Chinese Sci. Bull., 52, 1265-1273, https://doi.org/10.1007/s11434-0070165-5, 2007.

Miehe, S. and Miehe, G.: Ericaceous forest and heath land in Bale Mountains of South Ethiopia, Ecology and Man's Impact, Hamburg, Stiftung Walderhaltung in Africa Hamburg, Germany, 1994.

Messerli, B. and and Winiger, M.: Climate, Environmental Change, and Resources of the African Mountains from the Mediterranean to the Equator, Mt. Res. Dev., 12, 315-336, https://doi.org/10.2307/3673683, 1992.

Meyers, P. A.: Preservation of elemental and isotopic source identification of sedimentary organic matter, Chem. Geol., 114, 289302, https://doi.org/10.1016/0009-2541(94)90059-0, 1994.

Natelhoffer, K. J. and Fry, B.: Controls on Natural Nitrogen15 and Carbon-13 Abundances in Forest Soil Organic Matter, Soil Sci. Soc. Am. J., 52, 1633-1640, https://doi.org/10.2136/sssaj1988.03615995005200060024x, 1988.

Oades, J. M.: Soil organic matter and structural stability: mechanisms and implications for management, Plant Soil, 76, 319-337, https://doi.org/10.1007/BF02205590, 1984.

Prietzel, J., Dechamps, N., and Spielvogel, S.: Analysis of noncellulosic polysaccharides helps to reveal the history of thick organic surface layers on calcareous Alpine soils, Plant Soil, 365, 93-114, https://doi.org/10.1007/s11104-012-1340-2, 2013.

Sauheitl, L., Glaser, B., and Bol, R.: Short-term dynamics of slurry-derived plant and microbial sugars in a temperate grassland soil as assessed by compound-specific $\delta^{13} \mathrm{C}$ analyses, Rapid Commun. Mass Spec., 19, 1437-1446, https://doi.org/10.1002/rcm.1965, 2005.

Simoneit, B.: Molecular Indicators (Biomarkers) of past life, The Anatomical Record, 286, 186-195, https://doi.org/10.1002/ar.10153, 2002.

Solomon, D., Fritzsche, F., Lehmann, J., Tekalign, M., and Zech, W.: Soil organic matter dynamics in the sub-humid agroecosystems of the Ethiopian highlands: Evidence from natural $\mathrm{C}_{13}$ abundance and particle-size fractionation, Soil Sci. Soc. Am. J., 66, 969-978, 2002. 
Street-Perrott, F. A., Ficken, K. J., Huang, Y., and Eglinton, G.: Late Quaternary changes in carbon cycling on Mt. Kenya, East Africa: An overview of the $\delta^{13} \mathrm{C}$ record in lacustrine organic matter, Quat. Sci. Rev., 23, 861-879, https://doi.org/10.1016/j.quascirev.2003.06.007, 2004.

Tiercelin, J. J., Gibert, E., Umer, M., Bonnefille, R., Disnar, J. R., Lézine, A. M., Hureau-Mazaudier, D., Travi, Y., Keravis, D., and Lamb, H. F.: High-resolution sedimentary record of the last deglaciation from a highaltitude lake in Ethiopia, Quat. Sci. Rev., 27, 449-467, https://doi.org/10.1016/j.quascirev.2007.11.002, 2008.

Tiunov, A. V.: Stable isotopes of carbon and nitrogen in soil ecological studies, Biol. Bull., 34, 395-407, https://doi.org/10.1134/S1062359007040127, 2007.

Umer, M., Lamb, H. F., Bonnefille, R., Lézine, A. M., Tiercelin, J. J., Gibert, E., Cazet, J. P., and Watrin, J.: Late Pleistocene and Holocene vegetation history of the Bale Mountains, Ethiopia, Quat. Sci. Rev., 26, 2229-2246, https://doi.org/10.1016/j.quascirev.2007.05.004, 2007.

Wesche, K., Miehe, G., and Kaeppeli, M.: The Significance of Fire for Afroalpine Ericaceous Vegetation, Mt. Res. Dev., 20, 340-347, https://doi.org/10.1659/02764741(2000)020[0340:TSOFFA]2.0.CO;2, 2000.

Yimer, F., Ledin, S., and Abdelkadir, A.: Soil property variations in relation to topographic aspect and vegetation community in the south-eastern highlands of Ethiopia, For. Ecol. Manage., 232, 90-99, https://doi.org/10.1016/j.foreco.2006.05.055, 2006.

Yineger, H., Kelbessa, E., Bekele, T., and Lulekal, E.: Floristic Composition and Structure of the Dry Afromontane Forest At Bale Mountains National Park, Ethiopia, J. Sci., 31, 103-120, https://doi.org/10.4314/sinet.v31i2.66551, 2008.

Young, H. J. and Young, T. P.: Local distribution of C3 and C4 grasses in sites of overlap on Mount Kenya, Oecologia, 58, 373377, https://doi.org/10.1007/BF00385238, 1983.
Zech, M.: Evidence for Late Pleistocene climate changes from buried soils on the southern slopes of Mt. Kilimanjaro, Tanzania, Palaeogeogr. Palaeocl., 242, 303-312, https://doi.org/10.1016/j.palaeo.2006.06.008., 2006.

Zech, M. and Glaser, B.: Compound-specific $\delta^{18} \mathrm{O}$ analyses of neutral sugars in soils using gas chromatography-pyrolysis-isotope ratio mass spectrometry: Problems, possible solutions and a first application, Rapid Commun. Mass Spec., 23, 3522-3532, https://doi.org/10.1002/rcm.4278, 2009.

Zech, M., Zech, R., and Glaser, B.: A 240,000-year stable carbon and nitrogen isotope record from a loess-like palaeosol sequence in the Tumara Valley, Northeast Siberia, Chem. Geol., 242, 307318, https://doi.org/10.1016/j.chemgeo.2007.04.002, 2007.

Zech, M., Bimüller, C., Hemp, A., Samimi, C., Broesike, C., Hörold, C., and Zech, W.: Human and climate impact on ${ }^{15} \mathrm{~N}$ natural abundance of plants and soils in high-mountain ecosystems: A short review and two examples from the Eastern Pamirs and Mt. Kilimanjaro, Isotopes Environ. Health Stud., 47, 286296, https://doi.org/10.1080/10256016.2011.596277, 2011a.

Zech, M., Leiber, K., Zech, W., Poetsch, T., and Hemp, A.: Late Quaternary soil genesis and vegetation history on the northern slopes of Mt. Kilimanjaro, East Africa, Quat. Int., 243, 327-336, https://doi.org/10.1016/j.quaint.2011.05.020, 2011 b.

Zech, M., Rass, S., Buggle, B., Löscher, M., and Zöller, L.: Reconstruction of the late Quaternary paleoenvironments of the Nussloch loess paleosol sequence, Germany, using $n$-alkane biomarkers, Quat. Res., 78, 326-335, https://doi.org/10.1016/j.yqres.2012.05.006, 2012. 